\title{
Effect of Variety and Practice of Cultivation on Yield of Spring Maize in Terai of Nepal
}

\author{
Ghimire $\mathrm{S}^{1 *}$, Sherchan $\mathrm{DP}^{2}$, Andersen $\mathrm{P}^{3}$, Pokhrel $\mathrm{C}^{4}$, Ghimire $\mathrm{S}^{5}$ and Khanal $\mathrm{D}^{6}$ \\ ${ }^{1}$ Technical officer, Nepal Agricultural Research council, Nepal \\ ${ }^{2}$ ARTC Manager, Cereal System Initiative for South Asia, Nepal \\ ${ }^{3}$ Associate Professor, Departrment of Geography, University of Bergen, Norway \\ ${ }^{4}$ Associate Professor, Central Departrment of Botany, Tribhuvan University, Nepal \\ ${ }^{5}$ Assistant Manager, Rastriya Banijya Bank, Nepal \\ ${ }^{6}$ Senior Program Officer, Karuna Foundation Nepal
}

\begin{abstract}
A field experiment was conducted in farmer's field of MainaPokhar and Deudakala Village Development Committee in Bardiya District of Nepal. The objective of study was to identify the appropriate combination of variety and cultivation practice of maize in spring season. Two maize varieties Rajkumar (hybrid) and Arun2 (Open Pollinated Variety-OPV) were sown at the field of 6 different farmer's field. The experimental plot design was Randomized Complete Block Design with 6 replication and 4 treatments considering each farmer as a replication. There were 4 treatment combinations consisting two varieties and two practice of cultivations namely P1V1 (improved practice + Rajkumar), P1V2 (Improved practice+Arun2), P2V1 (Farmers practice + Rajkumar) and P2V2 (Farmers practice + Arun2). Result showed a significant $(P<0.01)$ differences among varieties. But no significant difference was found in yield by the interaction of variety and practice. The statistically analyzed results revealed that the effect of cultivation practice and their interaction effect on grain yield were found non-significant but the response of the variety were found highly significant difference on grain yield, where the Rajkumar variety produced the highest average grain yield of $5.13 \mathrm{t} / \mathrm{ha}$. It indicated that Rajkumar variety performs better than Arun2 in both improved and farmers practice of cultivation. Maximum grain yield ranging from ( 3.17 to $7.25 \mathrm{t} / \mathrm{ha}$ ) and (1.60 to $6.32 \mathrm{t} / \mathrm{ha}$ ) was produced by Rajkumar in improved practice and farmers practice of cultivation respectively while minimum grain yield was found in Arun2 ranging from (0.95 to $4.43 \mathrm{t} / \mathrm{ha})$ and $(0.81$ to $4.09 \mathrm{t} / \mathrm{ha})$ in improved practice and farmers practice of cultivation respectively. P1V1 scored the highest score followed by P2V1, P1V2 and P2V2 in farmers' preference ranking. Rajkumar variety cultivated with improved practice was found giving the best yield along with highest net return and Benefit Cost ratio of Rs. 30047.7 and 1.41 respectively.
\end{abstract}

Keywords: Maize; Hybrid; Open pollinated variety

\section{Introduction}

Agriculture is the mainstay of Nepalese economy. It also supplies about $80 \%$ of the country's total industrial raw materials and contributes about $70 \%$ of the total export earning of the country [1]. In Nepal, there is about 9,06,253 ha. of area under maize cultivation and annual production is about $20,67,722 \mathrm{smt}$. with productivity of $2.28 \mathrm{mt} / \mathrm{ha}$ [2]. Among cereals, maize is an important food and feed crop which ranks third after wheat and rice in world. As food producers are experiencing greater competition for land, water and energy, and the need to curb the many negative effects of food production on environment is becoming increasingly clear and this challenge requires changes in the way food is produced, stored, processed, distributed and accessed that are as radical as those that occurred in $18^{\text {th }}$ and $19^{\text {th }}$ century [3].

Nearly half the area under maize is planted with traditional varieties home saved seeds, which are continuously at the risk of degenerating (due to open pollination). The seed replacement rate is only $1 \%$. Manures and fertilizers are not applied in sufficient quantities [4]. Limited and irregular access of improved seeds and quality fertilizers specifically to the small holders in the remote villages is the main constraint for maize production [5]. Most of the farmers are not aware about information on crop management aspects particularly balances use of fertilizers and maintaining optimum plant population per hectare.

There is a big yield gap in maize for both mid hills and Tarai of Nepal. The experimental yield of OPV maize is $6.70 \mathrm{t} / \mathrm{h}$ a whereas attainable yield is $5.70 \mathrm{t} / \mathrm{ha}$. Attainable yield is the maximum experimental yields in farmers' fields. The national average of maize is $2.51 \mathrm{t} / \mathrm{ha}$ [6]. So the yield gap at present is $3.50 \mathrm{t} / \mathrm{ha}$. Similarly, the experimental yield of hybrid maize is $8.15 \mathrm{t} / \mathrm{ha}$ and attainable yield is $7.27 \mathrm{t} / \mathrm{ha}$, so the actual yield gap is $5.64 \mathrm{t} / \mathrm{ha}$ [7]. If we narrow down the yield gaps for both in OPVs and hybrids by $2 \mathrm{t} / \mathrm{ha}$, then yield would be double and the demand for grains and feeds will easily be met and fulfilled with this increment. Thus, the focus should be directed towards the arrowing of gaps through increasing access of improved seeds to the farmers and improved crop management practices.

Enhancing productivity of maize through identification of the best combination of management practice with preferred variety to add a brick in food security was the major goal of the experiment. In terai region cultivation of maize is done mostly in spring season; therefore this experiment was conducted with the objective:

1. To study the effect of varieties, cultivation practice and their interaction effect on yield of maize.

*Corresponding author: Ghimire S, Technical officer, Nepal Agricultura Research council, Nepal, Tel: + 97714256837; Fax: + 97714262500; E-mail: shantwana@narc.gov.np

Received March 07, 2016; Accepted May 28, 2016; Published June 03, 2016

Citation: Ghimire S, Sherchan DP, Andersen P, Pokhrel C, Ghimire S, et al. (2016) Effect of Variety and Practice of Cultivation on Yield of Spring Maize in Terai of Nepal. Agrotechnol 5: 144. doi:10.4172/2168-9881.1000144

Copyright: $\odot 2016$ Ghimire S, et al. This is an open-access article distributed under the terms of the Creative Commons Attribution License, which permits unrestricted use, distribution, and reproduction in any medium, provided the original author and source are credited. 
Citation: Ghimire S, Sherchan DP, Andersen P, Pokhrel C, Ghimire S, et al. (2016) Effect of Variety and Practice of Cultivation on Yield of Spring Maize in Terai of Nepal. Agrotechnol 5: 144. doi:10.4172/2168-9881.1000144

Page 2 of 6

2. To find out the farmer's preference for different combination of variety and practice.

3. To study and analyze the economic yield difference between the local variety and hybrid variety of maize under different management practice.

\section{Materials and Methods}

\section{Location}

The experiment was carried at 6 farmer's field 3 from Mainapokhar VDC and 3 from Deudakala VDC of Bardiya district from February, 2013 to July 2013 which was the command area of CSISA (Cereal System Initiatives for South Asia). The farmer's field was identified by the CSISA team. Geographically the study area is located in between $28^{\circ} 07^{\prime \prime}$ to $2839^{\prime \prime} \mathrm{N}$ in latitude and $81^{\circ} 03^{\prime \prime}$ to $81^{\circ} 41^{\prime \prime} \mathrm{E}$ in longitude.

\section{Cropping history and soil character of the field}

The experimental plot had potato-maize-rice sequential cropping pattern of one year rotation.

Soil samples were taken randomly from four different spots of each replication at a depth of $0-15 \mathrm{~cm}$ and found to be sandy loam and loam.

\section{Weather condition during experimentation}

The climate of the experimental site was characterized as tropical and dry. It was characterized by three distinct season i.e. rainy monsoon (June-October), cool winter (November-February), and hot spring (March-May). The maximum temperature during hot spring rises up to $39^{\circ} \mathrm{C}$ (May 2013) with minimum rainfall so the experimental plot faced problem of draught so that the germination was uneven because of drought and lack of irrigation facility. The draught problem also occurred during tasseling stage. The meteorological data of the cropping period was recorded from the meteorological station of Regional Agriculture Research Station, Khajura, Banke.

\section{Experimental design and data collection}

Two varieties of maize, Rajkumar and Arun2 were selected for the experiment. The seeds of these varieties were sown in the field of six different farmers, three each from two different VDCs of Bardiya. The experimental plot design was Randomized Complete Block Design with six replication and four treatments. Each farmer field was considered as a replication for the experiment whiles the four different combinations of varieties and practice of farming cultivation was considered as treatments. The four treatment combinations consisted of combination of two varieties and two practices of cultivations (Table 1). The area of individual plots for each treatment was $12 \mathrm{~m}^{*} 7 \mathrm{~m}$. The total plot area for all four treatment was $336 \mathrm{~m}^{2}\left(12^{*} 7^{*} 4 \mathrm{~m}^{2}\right)$ and the net experimental area including all four treatments and six replications was $2,016 \mathrm{~m}^{2}\left(12^{*} 7^{*} 4^{*} 6 \mathrm{~m}^{2}\right)$.

Fertilizer @120:60:60 N: $\mathrm{P}_{2} 0_{5}: \mathrm{K}_{2} \mathrm{O} \mathrm{kg} / \mathrm{ha}$ (This dosage of fertilizer is the recommendation from NARC (National Agricultural Research Center)).

For Basal dose: @ 60:60:60 N: $\mathrm{P}_{2} 0_{5}: \mathrm{K}_{2} \mathrm{O}$ kg/ha i.e (79.43:130.34:100 Urea:DAP:MOP kg/ha).

$1^{\text {st }}$ Top dress: @ $30 \mathrm{~N} \mathrm{kg/ha} \mathrm{i.e.} \mathrm{(65.21} \mathrm{Urea} \mathrm{kg/ha).}$

$2^{\text {nd }}$ Top dress: @ $30 \mathrm{~N} \mathrm{~kg} /$ ha i.e. (65.21 Urea kg/ha).

Weeding: 1 time

Irrigation: 3 times
Row to row and plant to plant distance of $70^{*} 20 \mathrm{~cm}$ was maintained.

$\mathrm{P}_{2}=$ farmers practice

Fertilizer @53.2:30.4:0 N: $\mathrm{P}_{2} 0_{5}: \mathrm{K}_{2} \mathrm{O} \mathrm{kg} / \mathrm{ha}$

Basal dose: @ 26.6:30.4:0 N: $\mathrm{P}_{2} 0_{5}: \mathrm{K}_{2} \mathrm{O}$ kg/ha i.e. (31.98:66.08:0 Urea:DAP:MOPKg/ha)

Top dress: @ 26.6 N kg/ha i.e. (57.82:0:0 Urea Kg/ha)

Weeding: 1 time

Irrigation: 3 times

Row to row and plant to plant distance of $70^{*} 20 \mathrm{~cm}$ maintained.

\subsection{Factor B (Varieties)}

V1: RajKumar (Hybrid)

V2: Arun2 (Open Pollinated Variety)

\section{Cultural Practice}

\section{Field preparation}

The field was ploughed 15 days before sowing to incorporate the weed and crop residue in to the soil.

\section{Fertilizer application}

In improved practice, the maize crop was fertilized with @120:60:60 $\mathrm{N}: \mathrm{P}: \mathrm{K} \mathrm{Kg} / \mathrm{ha}$ through Urea, DAP and MOP in 3 split dose. The recommended amount of nitrogen, phosphatic and potassic fertilizers @ 60:60 kg/ha were calculated and weighed separately for and were applied in all experimental plots.

In farmers practice, the maize crop was fertilized with @ 53.2:30.4:0 $\mathrm{N}: \mathrm{P}: \mathrm{K} \mathrm{kg} / \mathrm{ha}$ in two split dose through Urea, DAP and MOP. The recommended amount of nitrogen fertilizer was calculated and weighed separately and was applied in all experimental plots. Fertilizer application was done @120:60:60 N: $\mathrm{P}_{2} 0_{5}: \mathrm{K}_{2} \mathrm{O} \mathrm{kg} / \mathrm{ha}$ in three split dose in improved practice.

For Basal dose: @ 60:60:60 N: $\mathrm{P}_{2} 0_{5}: \mathrm{K}_{2} \mathrm{O}$ kg/ha i.e (79.43:130.34:100 Urea:DAP:MOP kg/ha)

$1^{\text {st }}$ Top dress: @ $30 \mathrm{~N} \mathrm{~kg} / \mathrm{ha}$ i.e. (65.21 Urea kg/ha)

$2^{\text {nd }}$ Top dress: @ $30 \mathrm{~N} \mathrm{kg/ha}$ i.e. (65.21 Urea kg/ha)

And application of fertilizer in farmers practice was done @53.2:30.4:0 N: $\mathrm{P}_{2} 0_{5}: \mathrm{K}_{2} \mathrm{O} \mathrm{kg} /$ ha in two split dose.

Basal dose: @ 26.6:30.4:0 N: $\mathrm{P}_{2} 0_{5}: \mathrm{K}_{2} \mathrm{O} \mathrm{kg} / \mathrm{ha}$ i.e. (31.98:66.08:0 Urea:DAP:MOP Kg/ha)

Top dress: @ 26.6: N kg/ha i.e. (57.82 Urea Kg/ha).

\section{Seed sowing}

The required amount of seed of all varieties each individual plot was calculated. The seed rate of @ $30 \mathrm{~kg} / \mathrm{ha}, 252 \mathrm{gm}$ for each individual

\begin{tabular}{|c|c|c|c|}
\hline S.No & Cultivation Practice (P) & Variety (V) & Notation \\
\hline 1 & Improved Practice 120:60:60NPK kg/ha & Rajkumar & P1V1 \\
\hline 2 & Improved Practice 120:60:60NPK kg/ha & Arun2 & P1V2 \\
\hline 3 & Farmers Practice 53.2:30.4:0 NPK kg/ha & Rajkumar & P2V1 \\
\hline 4 & Farmers Practice 53.2:30.4:0 NPK kg/ha & Arun2 & P2V2 \\
\hline \multicolumn{2}{|l}{ Treatment Details: Factor A (Cultivation Practice), $\mathrm{P}_{1}=$ improved practice } \\
\hline
\end{tabular}

Table 1: Treatment Combination. 
Citation: Ghimire S, Sherchan DP, Andersen P, Pokhrel C, Ghimire S, et al. (2016) Effect of Variety and Practice of Cultivation on Yield of Spring Maize in Terai of Nepal. Agrotechnol 5: 144. doi:10.4172/2168-9881.1000144

Page 3 of 6

plot $\left(84 \mathrm{~m}^{2}\right)$ was used. Bold, biophysically good, healthy seeds of both varieties were selected and two seeds per hill were dropped manually in the row line. Maize seeds were sown maintaining $20 \mathrm{~cm}$ between plant to plant and row to row distance $70 \mathrm{~cm}$. The sowing was done in 2013 , February 27 (Table 2).

\section{Thinning}

Thinning was done on the $20^{\text {th }}$ Days after Seeding (DAS) for all treatment to maintain a single plant per hill spot by removing all the other extra and weaker maize plant.

\section{Plant protection}

Stem borer was found problematic in the field at earlier 8 to 10 leaves stage of maize plant. Furadon @ $1 \mathrm{~kg} /$ Kattha $\left(333.3 \mathrm{~m}^{2}\right)$ was applied against the stem borer which was applied in all part of leaf at grand growth stage (40 DAS). Grasshopper was also found to be problematic in the field. Chlorpyriphos $50 \%+$ Cypermethrin $5 \%$ at interval of 1 week for 3 times.

\section{Weeding and irrigation}

Manual weeding was done at knee high stage. Irrigation was provided just for 3 times at critical growth stages because of poor irrigation facility.

\section{Harvesting and threshing}

The whole plot was harvested manually when the plant turned to yellowish, ear husk turned into the brown and appearance of black layer at the base of each kernel when scratched by cutting plants with sickles near the ground level. Threshing of grain was done manually after the sun drying of harvested crop and grains were cleaned by winnowing and separately dried by maintaining $15 \%$ moisture. Harvesting of Arun2 (June $5^{\text {th }}, 2013$ ) was done 7-13 days before Rajkumar variety (18 ${ }^{\text {th }}$ June, 2013) (Table 3).

\section{Preference ranking}

A survey was done for ranking the preference of the farmers regarding the cultivation practice and variety. The survey was done by conducting Farmer's Field Day where farmers were given the form for evaluating the experiment by 8 different attributes (Days to maturity, leaf color, plant quality, cob per plant, length of cob, probable green cob, insect tolerance and overall quality). 27 farmers were taken for conducting this survey, forms were compiled and Garret ranking was done. (Form can be found in annex).

Garret analysis was done by using the formula

$$
\text { PercentagePosition }=100\left(\frac{R i j-0.5}{N j}\right)
$$

Where,

$\mathrm{R}_{\mathrm{ij}}=$ Rank given for $\mathrm{i}^{\text {th }}$ item by $\mathrm{jth}$ individual

$\mathrm{N}_{\mathrm{j}}=$ Number of items ranked by $\mathrm{j}^{\text {th }}$ individual

\begin{tabular}{|c|c|c|c|c|c|}
\hline Varieties & $\begin{array}{c}\text { Maturity } \\
\text { days }\end{array}$ & \multicolumn{4}{|c|}{ Yield } \\
\hline & & $\begin{array}{c}\text { Improved } \\
\text { practice } \\
\text { (Average) t/ha }\end{array}$ & $\begin{array}{c}\text { Farmers } \\
\text { practice } \\
\text { (Average) t/ha }\end{array}$ & $\begin{array}{c}\text { Maximum } \\
\text { (Improved) }\end{array}$ & $\begin{array}{l}\text { Minimum } \\
\text { (Farmers) }\end{array}$ \\
\hline Rajkumar & 100 & $5.14(1.67)$ & $3.96(1.75)$ & $7.25 \mathrm{t} / \mathrm{ha}$ & $3.17 \mathrm{t} / \mathrm{ha}$ \\
\hline Arun2 & 85 & $2.93(2.10)$ & $2.11(1.38)$ & $4.43 \mathrm{t} / \mathrm{ha}$ & $0.71 \mathrm{t} / \mathrm{ha}$ \\
\hline
\end{tabular}

Note: Value in ( ) indicates standard deviation.

Table 2: Varieties their maturity days with maximum, minimum and mean yield with standard deviation.

\begin{tabular}{|c|c|c|c|c|}
\hline S.N & Cultivation Practice & Variety & Treatment & Ranking \\
\hline 1 & Improved Practice & Rajkumar & P1V1 & I \\
\hline 2 & Improved Practice & Arun2 & P1V2 & III \\
\hline 3 & Farmers Practice & Rajkumar & P2V1 & II \\
\hline 4 & Farmers Practice & Arun2 & P2V2 & IV \\
\hline
\end{tabular}

Table 3: Preference Ranking Table.

\section{Measurement of yields}

Grain yield: After drying and shelling of the harvested produce of each sample plant of individual plot, the grain yield was recorded. Grain yield was calculated on hectare basis by using following formula:

$$
\text { Grain yield }(\mathrm{kg} / \mathrm{ha})=\frac{\frac{\text { Fresh wt }}{\text { Area in } \mathrm{m}^{2}} \times(100-\text { moisture } \%)}{(100-15 \% \text { adjusted })} \times 10000
$$

\section{Economic Analysis}

1. Cost of Cultivation: Cost of cultivation was calculated on the basis of available local charges for different agro-inputs viz. price of seed, labor charge, fertilizers, bullocks and other necessary materials.

2. Gross return: Economic yield was converted into gross return on the basis of market price of maize grain. The grain yield was calculated as per local prices Rs. $20 / \mathrm{kg}$ grain.

3. Net return: It was calculated by deducting the cost of cultivation from the gross return.

Net return $(\mathrm{Rs} / \mathrm{Ha})=$ Gross return - Total cost

4. Benefit cost ratio: Benefit cost ratio was calculated as below:

Benefit:cost ratio(B:C ratio $)=\frac{\text { Gross income }(\mathrm{Rs} / \mathrm{Ha})}{\text { Total } \operatorname{cost}(\mathrm{Rs} / \mathrm{Ha})}$

\section{Statistical Analysis}

Microsoft Office package (MS Excel and MS word) were used extensively to feed in the primary data, make basic tables, charts and type in the overall text. The data was first tabulated in Microsoft Excel and effect of variety on yield and effect of practice of cultivation on yield were statistically analyzed by using $\mathrm{R}(64 \times 2.15 .1$ version) program (Table 4).

\section{Results}

The experimental results were analyzed and presented in this chapter with figures and tables where necessary (Figure 1-4).

\section{Effect of cultivation practice and varieties on grain yield ( $t /$} ha)

Grain yield of a crop is the result of combined effect of growth, development and yield attributes. These parameters are governed by the heredity of the particular variety but at the same time these are also modified by the level of management and the environmental to which the crop is exposed.

Effect of practice of cultivation in yield: Grain yield was not significantly influenced by practice of cultivation. However, higher yield was found in Rajkumar variety with improved practice. The hybrid variety Rajkumar gave higher yield of $4.54 \mathrm{t} / \mathrm{ha}$ in average where as Arun2 produced the mean grain yield $2.52 \mathrm{t} / \mathrm{ha}$. The effect of farmers practice in yield of maize was found to be non-significant $(\mathrm{p}>0.05)$.

Effect of variety in yield: There was significant $(\mathrm{P}<0.05)$ difference in the grain yield between varieties. Grain yield was significantly 


\begin{tabular}{|c|c|c|c|c|}
\hline Treatments & $\begin{array}{c}\text { Gross return } \\
\text { per hectare Rs }\end{array}$ & $\begin{array}{c}\text { Cost per } \\
\text { hectare Rs }\end{array}$ & $\begin{array}{c}\text { Net return per } \\
\text { hectare Rs }\end{array}$ & B:C ratio \\
\hline T1(P1V1) & 102600 & 72552.3 & 30047.7 & 1.41 \\
\hline T2(P1V2) & 58200 & 66402.3 & -8202.3 & 0.88 \\
\hline T3(P2V1) & 78600 & 82038 & -3438 & 0.96 \\
\hline T4(P2V2) & 42000 & 75888 & -33888 & 0.55 \\
\hline Mean & 70350 & 74220.15 & -3870.15 & 0.95 \\
\hline
\end{tabular}

Table 4: Revenue, Cost, Net Return and B:C ratio.

\section{Avg Rainfall (mm)}

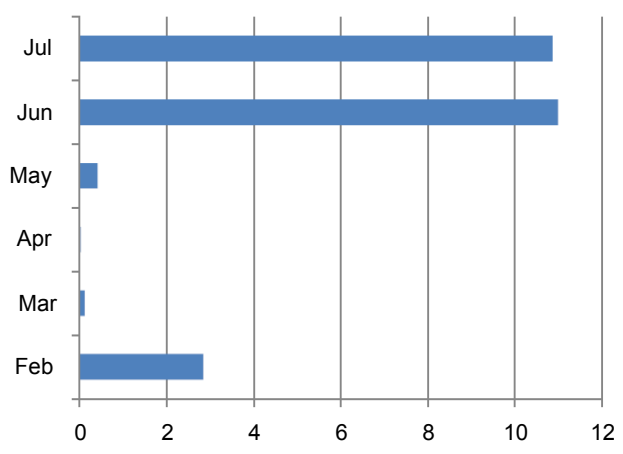

Figure 1: Average Rainfall in millimeters

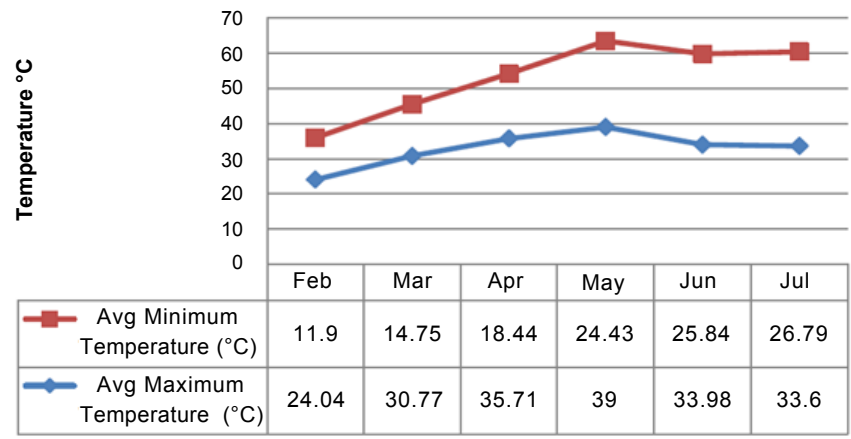

Figure 2: Temperature during experimental period.

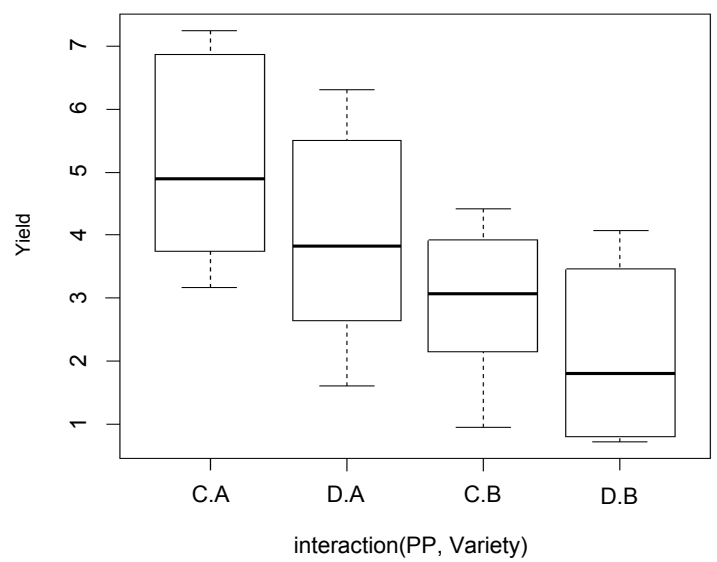

Figure 3: Boxplot showing difference in yield (t/ha) for different practice of cultivation. C.A=Improved practice of cultivation+Rajkumar; D.A= Farmers practice of cultivation+Rajkumar; $C . B=$ Improved practice of cultivation+Arun2; D.B= Farmers practice of cultivation+Arun2).

\section{Preference Ranking}

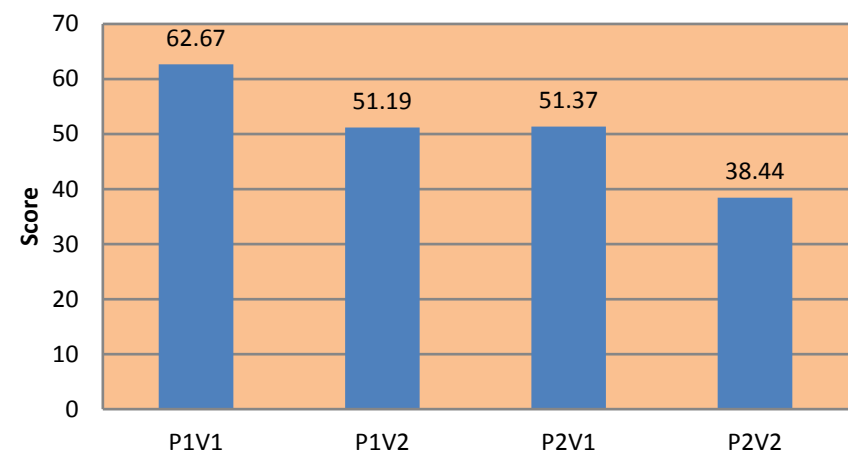

Figure 4: Graph representing preference ranking of individual treatment.

affected by crop varieties sown. Irrespective of fertilizer dose and irrigation maximum grain yield ranging from (3.17 to $7.25 \mathrm{t} / \mathrm{ha}$ ) and ( 1.60 to $6.32 \mathrm{t} / \mathrm{ha}$ ) was produced by Rajkumar in improved practice and farmers practice of cultivation respectively. While minimum grain yield was found in Arun2 ranging from (0.95 to $4.43 \mathrm{t} / \mathrm{ha}$ ) and (0.81 to $4.09 \mathrm{t} / \mathrm{ha}$ ) in improved practice and farmers practice of cultivation respectively.

While performing two-way ANOVA with the data having two predicting variable with two categorical values of each; we get the result that the interaction affect between the practices and varieties was not significantly performing to give the result in yield. And after running the linear model with interaction effect eliminated; we found that not practice but varieties of the species are significantly different to give different result in yield.

\section{Preference ranking}

Preference ranking was done conducting farmers field day. Analysis of the collected data was done through Garret ranking. Average of each treatment was calculated and percent and score were calculated accordingly. And the average of the score of each treatment was calculated to get the final result of ranking which is presented below.

Treatment P1V1 was at the first rank which means it is the most preferred and P2V1, P1V2, and P2V2 on the second, third and fourth respectively.

From the result of garret ranking we came to know that the combination of Rajkumar variety and improved practice got the first rank considering the 8 attributes (Days to maturity, leaf color, plant quality, cob per plant, length of cob, probable green cob, insect tolerance and overall quality). P1V1 is in the first rank with highest score which is the combination of Rajkumar variety and improved practice. Similarly, P2V1 got the $2^{\text {nd }}$ rank which is the combination of Rajkumar variety and farmers practice followed by P1V2 and P2V2. Here the treatment which got the highest and second highest score differs only in variety which means if hybrid variety is adopted for farming we can get the good yield.

\section{Economic Analysis}

The economics of various treatments under study was worked out to evaluate the most beneficial combination of cultivation practice and maize cultivars. 


\section{Cost of cultivation}

The cost of cultivation for Improved farming practice was higher than the cost of cultivation for Farmers Practice but the return was also higher in improved farming. The cost of cultivation is the total expenditure incurred for raising crops in cropping system. Cost of cultivation was calculated on the basis of local charges for different agro-inputs viz. labor, fertilizer, compost and other necessary materials.

\section{Gross return}

The total monetary economic produce and by products obtained from the crop is called gross return. It is calculated based on the local market price of the produce. The mean gross return of the experiment was Rs 70350 per hectare and ranging from Rs 42000 to Rs 102600.

\section{Net return}

Net return is the ultimate product obtained by subtracting cost of cultivation from gross return. It is a good indicator of sustainability of crop since this represents the actual income of the famer. It was calculated by subtracting the cost of cultivation from the gross return. The mean net return of the experiment was (-Rs 3870.15) and it ranged from Rs (-33888 to 30047.70) per hectare.

\section{$\mathrm{B}: \mathrm{C}$ ratio}

Benefit cost ratios the ratio of gross return to cost of cultivation which can also be expressed as returns per rupee invested. Any value greater than 2 is considered safe as the farmer gets 2.00 for every rupee invested. On the other hand $\mathrm{B} / \mathrm{C}$ ratios of 1 for the agricultural sector have been fixed for any enterprises to be economically viable. Therefore any crop enterprise must maintain a $1 \mathrm{~B}: \mathrm{C}$ ratio to be economically sustainable (Bhandari, 1993). The mean B:C ratio in the experiment was 0.95 and ranged from 0.55101 .41 . Rajkumar variety grown under improved cultivation practice was the most cost effective farming practice because only $\mathrm{P} 1 \mathrm{~V} 1$ had a ratio $>1$, based on the price relations used in the calculation.

Since B:C ratio is higher in T1 (1.41) with net return of Rs 30047.7, we can conclude that the combination of improved cultivation practice with Rajkumar variety is the best and most cost effective. Since B:C ratio and net return of $\mathrm{T} 1$ and $\mathrm{T} 3$ are higher as compared to T2 and $\mathrm{T} 4$ we can say that Rajkumar is the superior variety as it is performing better in farmers cultivation practice also. Talking about Arun2, its combination with improved practice also didn't give the satisfactory results, not only because Rajkumar cultivated with farmers method cultivation is performing better than Arun2 with improved method of cultivation, but also because the economic return is not satisfactory.

\section{Discussion}

Significantly higher yield by hybrid maize cultivated with improved practice is due to exploitation of hybrid vigor when growth environment is provided during the life cycle $[8,9]$. Reported that the genotypic constitution largely determine the response of a variety to chemical fertilizers. Terai and inner Terai of Nepal is highly potential for hybrid cultivation particularly in spring and winter seasons [10]. Development and use of hybrid seeds can enhance crop yields and performance in ways that are different from and not necessarily dependent on heterosis by itself [11]. OPV's may be a valuable option for maize producers under some circumstances, but the use of an OPV or recycled seed would be a step backward for grain yield. Generally, a hybrid will produce $18 \%$ more grain than most of the better OPV [12]. In this experiment, yield of Rajkumar was found to be $42.99 \%$ and $46.71 \%$ more than Arun2 in improved practice and farmers practice respectively. Response by farmers in farmer's field day for preference ranking was very much positive about Rajkumar variety as it performed best in poor irrigated condition also. Hybrid maize technology has made significantly yield advances and increased productivity in both developed and developing countries [13]. The replacement of open pollinated varieties by hybrids is an effective way to enhance productivity [10].

Yield is not determined nor only by the variety neither the practice of cultivation but with the perfect combination of both. Poor variety with best practice may be performing far better than best variety with poor practice. But the best variety with best practice will surely perform the best in grain yield which is P1V1 in our research which is the combination of Rajkumar variety and improved cultivation practice. Farmers' preference was towards Rajkumar in different attributes and overall quality considered. Farmers' preference to green cob was also higher in Rajkumar variety. Rajkumar variety performed best in both practice of cultivation with poor irrigation facility. The maize hybrids performed exceptionally better during drought stress [14]. It is well recognized fact that cultivation of hybrids maize cultivars is one of the best alternatives to increase the production and productivity of maize in Nepal [10]. The statistically analyzed results revealed that the effect of cultivation practice and their interaction effect on grain yield were found non-significant but the response of the variety were found highly significant difference on grain yield, where the hybrid variety, Rajkumar produced the highest average grain yield of $5.13 \mathrm{t} /$ ha. Similar result was found by [15] while comparing Rajkumar with other varieties. Among the two varieties Arun2 and Rajkumar, variety Rajkumar has high benefit: cost ratio under both improved and farmers practice 1.41 and 0.96 respectively. However, Stover yield was not taken into consideration because farmers deny to harvest due to storage problem. The higher yields and revenues (including the market value of home-consumed maize) of hybrids outweighed the higher costs of hybrid maize cultivated with improved practice of cultivation method.

\section{Conclusion}

Hybrid maize is suitable for higher production and has higher potential than OPVs in the Terai condition. Choosing wrong variety may result loss of yield, resulting in food insecurity and loss of profits. Irrespective cultivation practices Rajkumar hybrid was found to be superior during spring season in Terai region. Economic analysis depicted that the highest net return was observed in Rajkumar Hybrid in improved practice of Rs. 30047.7 with B:C ratio 1.41 which scored highest in preference ranking and gave $42.99 \%$ more yield than Arun2. Finally, the most important thing is to develop crop production technology with emphasis on cost reducing, input efficient seed production technology and soil fertility improvement.

\section{Acknowledgement}

I would like to express my deepest gratitude Dr. Medha Devare and CSISA-Np family. I am ever indebted to Dr. Ole R. Vetaas and Dr. Ram Prasad Chaudhary. I want to thank Head of Department Prof. Pramod K. Jha and all the Department of Botany family for their cooperation. Special thanks farmers from research site who provided the field to conduct research and NARC family.

\section{Reference}

1. Gurung DB (2006) Genetic diversity, heterosis and combining ability with Nepalese maize varieties. Science City of Mufloz, Nueva Ecija, Phillipines: Central Luzon State University.

2. MOAC (2011) In Krishi Diary 2069. Hariharbhawan: Agriculture Information and Communication Centre.

3. Charles JGH, Beddington RJ, Crute RI, Lawrence H, David L et al. (2010) Food Security: The Challenge of Feeding 9 Billion people. Science, 327: 812-818. 
Citation: Ghimire S, Sherchan DP, Andersen P, Pokhrel C, Ghimire S, et al. (2016) Effect of Variety and Practice of Cultivation on Yield of Spring Maize in Terai of Nepal. Agrotechnol 5: 144. doi:10.4172/2168-9881.1000144

Page 6 of 6

4. Koirala GP (2001) Factors Affecting Maize Production, productivity and Trade in Nepal. Kathmandu Nepal: CIMMYT, NMRP.

5. NMRP (2011) Annual Report. Rampur Chitwan Nepal: National Maize Research Program.

6. Nepal GO (2013) Krishi Diary. Hariharbhawan Lalitpur: Agriculture Information and Communication Center.

7. Acharya SR (2011) Production potential and economic viability of winter maize cultivars under different nitrogen levels in irrigated condition. Postgraduate Dissertation. Rampur, Chitwan: Institute of Agriculture and Animal Sciences.

8. Pokhrel B (2006) Response to two maize cultivars to different level of nitrogen during winter season at rampur, Chitwan. Rampur, Chitwan, Nepal: Institution of Agriculture and Animal Sciences, Tribhuvan University.

9. Singh K, Prasad P (1990) Response of promising rainfed maize (Zea mays) varieties to nitrogen application in north-western Himalayan region. Indian Journal of Agriculture Sciences, 7: 475-477.
10. Kunwar CB, Shrestha J (2014) Evaluating Performance of Maize hybrids in Terai Region of Nepal. World Journal of Agricultural Research, 2: 22-25.

11. Duvick DN (1999) Heterosis: Feeding people and protecting natural resources American Society of Agronomy, 19-29.

12. Anonymus (2011) Hybrid or open pollinated variety seed-weigh up the option Bothaville, 9660: GRAIN SA.

13. Katuwal RB (2012) Influence of variety and planting date on cold tolerance and yield for winter maize in Nepal. Chitwan, Rampur: Institute of Agriculture and Animal Science.

14. Oyekale KO, Dainel IO, Kamara AY, Akintobi DA, Adedbite A E Evaluation of Maize Hybrids for Yield Characteristics under Drought Stress. Ibadan, Nigeria: International Institute of Tropical Agriculture.

15. Dawadi DR, Sah SK (2012) Growth and Yield of Hybrid Maize (Zea mays L.) In Relation to Planting Density and Nitrogen Levels during Winter Season in Nepal. Tropical Agricultural Research 23: 218-227. 